\title{
Effect of enzyme supplementation of diets based on maize or hominy feed on performance and nutrient digestibility in broilers
}

\author{
S. Kaczmarek ${ }^{1}$, M. Bochenek, D. Józefiak and A. Rutkowski \\ Poznan University of Life Sciences, Department of Animal Nutrition and Feed Management \\ Wotyńska 33, 60-637 Poznań, Poland
}

(Received 14 December 2007; revised version 17 November 2008; accepted 23 January 2009)

\begin{abstract}
Two experiments were conducted to determine the nutritional value of hominy feed and impact of an enzyme preparation in broiler chickens diets. In the first experiment, 480 one-day-old chickens were fed 6 experimental diets (treatments) from the day of hatching to 35 days of age with increasing quantities of hominy feed replacing 0,50 and $100 \%$ of maize. The diets were fed with or without enzyme supplementation. Each treatment consisted of 10 replications, 8 birds per replication. During the entire period, chickens from the group receiving maize had a lower $(\mathrm{P}<0.05)$ feed conversion ratio (FCR) in comparison with other experimental groups. Body weight gains were also reduced $(\mathrm{P}<0.05)$ when maize was substituted by hominy feed. Addition of enzymes improved FCR $(\mathrm{P}<0.05)$. Experiment two was carried out using 120, 21-day-old Ross male chickens in 10 treatments, 12 birds per experimental group. Birds fed maize hominy diets had the lowest organic dry matter and $\mathrm{N}$-free extractives apparent digestibility coefficient $(\mathrm{P}<0.05)$. Hominy diets also had a lower $\mathrm{AME}_{\mathrm{N}}$ value $(\mathrm{P}<0.05)$. Enzyme addition improved the apparent digestibility of all nutrients $(\mathrm{P}<0.05)$ except crude fat.
\end{abstract}

KEY WORDS: broiler chickens, maize, hominy feed, enzyme preparation, performance, digestibility

\section{INTRODUCTION}

Maize is one of the main cereals used in feeding broiler chickens worldwide. It is free of viscous non-starch polysaccharides, the major anti-nutritive factors

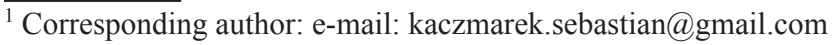


present in most other cereals like barley, wheat, and oats, but induces yellow skin pigmentation, which may not be accepted by some consumers.

The production of maize in Poland in 2005 reached 1.9 million tons, increasing by over 1.3 million tons since 1999 (FAOSTAT Database, 2006). By-products from the processing of maize are good feed for animals, but due to their relatively high fibre content, they are better utilized by cattle and sheep than by poultry and pigs. At present, the feed industry uses maize as a basic energy source in poultry diets, but its price is very high. New, high-energy and cheaper feeds are by-products from wheat and maize processing (NRC, 1994; Stock et al., 2000; Rodrigues et al., 2001; Boros et al., 2004, Slominski et al., 2004) that can be successfully used in broiler production. The nutritive value of maize by-products depends on the technological processes used, such as milling, de-germing, oil extraction, and starch separation (Stock et al., 2000). One of many maize by-products is the maize grits by-product, or hominy feed, a mixture of maize bran, maize germ, and part of the starch. Hominy feed is a by-product formed during dry maize milling for table maize meal, production of pearl hominy and maize grits. The object of this process is to separate endosperm, while removing as much of the germ and pericarp as possible (Stock et al., 2000). The nutritional value of hominy feed was investigated by Rodrigues et al. (2001), in trials on broilers and adult cockerels.

Exogenous enzymes have been used for many years to break down cell walls in feed ingredients, to reduce the viscosity of digesta and to improve the digestibility of carbohydrates and protein (Bedford and Morgan, 1996). Generally, they are used to improve the nutritive value of wheat- and barley- based diets, but some enzyme preparations are also used to increase the nutritional value of maize and its by-products (Boros et al., 2004). Cowieson (2005) reported that an enzyme preparation added to a diet based on maize improved feed conversion ratio from 0.78 to $10.5 \%$ and body weight gain from 0.5 to $10.9 \%$ over the control. Low-viscosity diets are considered energy dense, but nutrient availability may still be improved. Chesson (2001) reported that maize kernel contains 111 $\mathrm{g} \cdot \mathrm{kg}^{-1}$ of total non-starch polysaccharides, of which $230 \mathrm{~g} \cdot \mathrm{kg}^{-1}$ is arabinose and $300 \mathrm{~g}^{*} \mathrm{~kg}^{-1}$ is xylose. That report could warrant the use of exogenous enzymes (xylanase, $\beta$-glucanase, pectinase, cellulase, mannanase, and galactanase) to increase the digestibility of nutrients found in the maize kernel (Meng and Slominski, 2005).

The aim of the present study was to compare the nutritional value of maize and hominy feed with or without an enzyme preparation in studies on broiler chickens. 


\section{MATERIAL AND METHODS}

The sample of hominy feed (maize grits by-product) used in the study was obtained from Bio Corn Company. This product was formed during dry maize milling for table maize meal, production of pearl hominy, and maize grits. At the beginning maize was screened initially to remove crop residues, fines, and broken kernels, and then it was washed and tempered with water or steamed to achieve a moisture content of about $200 \mathrm{~g} \cdot \mathrm{kg}^{-1}$. Then, using a de-germinator, germ and pericarp were separated from endosperm. The purpose of this process is to isolate the maximum amount of endosperm (starch) by removing as much germ and pericarp as possible. However, the separation of endosperm fractions is incomplete, resulting in residual germ and pericarp remaining attached to the endosperm. These remains are subsequently removed by aspiration and screening and next sorted by size to yield large, medium, or fine grits, meals, or flours. Feed by-products of this dry-milling process include bran, broken kernels, germs and inseparable fractions of germ, pericarp, and endosperm; optionally oil is also removed from germs. These materials usually are marketed as maize grits byproduct, or hominy feed, or Corn Mix on the Polish feed market.

\section{Experiment 1}

The experiment was conducted with 480 one-day-old Ross 308 male chickens. On arrival, $10 \%$ of the birds were weighed and average arrival weight of the flock was calculated. Birds were kept in 60 floor pens, 8 cockerels per pen (16 birds per $\mathrm{m}^{2}$ ). The room environment was managed according to the requirements for broiler chickens. All diets were formulated to be isonitrogenous and isocaloric (Table 1). All birds were fed ad libitum, mash diets, Starter from day 1 to 14, Grower from day 15 to 35 . Maize-based diets were used in groups M and M+E. Birds from groups $\mathrm{MB}$ and $\mathrm{MB}+\mathrm{E}$ were offered diets based on maize grain and hominy feed. Birds from groups $\mathrm{B}$ and $\mathrm{B}+\mathrm{E}$ received hominy feed-based diets. In addition, diets in groups: $\mathrm{M}+\mathrm{E}, \mathrm{MB}+\mathrm{E}, \mathrm{B}+\mathrm{E}$, were supplemented with an enzyme preparation (Avizyme 1500, Danisco Animal Nutrition, UK). The feed enzyme Avizyme 1500 contained per g: protease (Bacillus subtilis) $4000 \mathrm{U}$, alfa-amylase (Bacillus amyloliquofaciens) $400 \mathrm{U}$, xylanase (Trichoderma longibrachiatum) $300 \mathrm{U}$ and pectinase (Aspergillus aculeatus) $25 \mathrm{U}$ (according to the producer's declaration).

Body weight (BW) and feed intake (FI) were measured in weekly intervals, while the body weight gain (BWG) and feed conversion ratio (FCR) were calculated at the end of the trial. During one day in the fifth week of the experiment, 10 chickens from each group were sacrificed by cervical dislocation. Birds were 


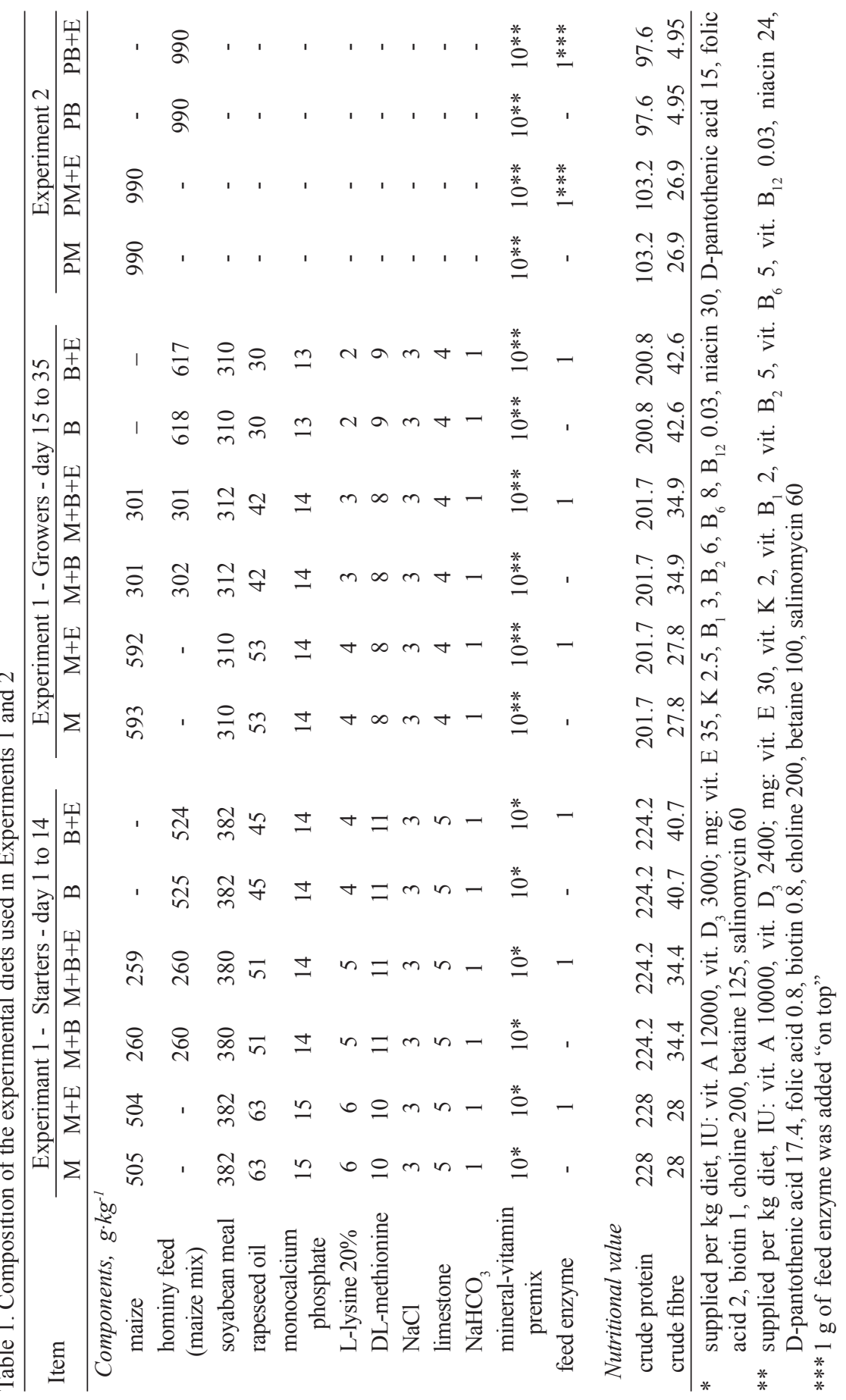


slaughtered with the aim to perform a simplified post-slaughter analysis which comprised: determination of dressing percentage as well as the proportion of breast muscles and abdominal fat as compared with carcass weight. The eviscerated carcass (with neck and the ends of wings) without giblets was weighed to determine hot dressed yield. All weights were recorded to the nearest $0.1 \mathrm{~g}$.

\section{Experiment 2}

One hundred and twenty, 21-day old Ross male chickens with a mean BW of $377 \mathrm{~g}$ were used in the experiment. A total of 10 experimental groups was replicated 12 times. Six experimental groups received grower diets from Experiment 1 (Table 1). Broilers from group $\mathrm{PM}$ and $\mathrm{PM}+\mathrm{E}$ were offered diets composed with maize $990 \mathrm{~g} \cdot \mathrm{kg}^{-1}$ and $10 \mathrm{~g} \cdot \mathrm{kg}^{-1}$ grower vitamin-mineral premix, while in groups $\mathrm{PB}$ and $\mathrm{PB}+\mathrm{E}$, the diets were composed with $990 \mathrm{~g} \cdot \mathrm{kg}^{-1}$ hominy feed and $10 \mathrm{~g} \cdot \mathrm{kg}^{-1}$ grower vitamin-mineral premix. Diets in groups $\mathrm{PM}+\mathrm{E}$ and $\mathrm{PB}+\mathrm{E}$ were supplemented with the same enzyme preparation as in other diets (Table 1).

The birds were kept individually in balance cages. The chickens received mash diets ad libitum. The balance trial lasted eight days and was divided into two periods: a preliminary $5 \mathrm{~d}$ period to adapt the birds to balance cages and a $3 \mathrm{~d}$ excreta collection period which started and finished with $12 \mathrm{~h}$ feed deprivation. In the last period, feed intake was strictly recorded and excreta were collected quantitatively two times per day and immediately frozen at $-18^{\circ} \mathrm{C}$.

\section{Analytical methods}

The samples of hominy feed (Corn-Mix) used in the study were obtained from Bio Corn Company. The concentration of dry matter, crude protein, crude fat and crude fibre in maize grain, hominy feed, diets and excreta were determined using the AOAC (1992) procedure. Crude protein was determined by the Kjeldhal method (Foss Electric Company, Denmark).

Prior to analysis, excreta samples were homogenized with the use of stomacher homogenizer (Interscience, France), then freeze-dried (Christ 1825 Medizinische Apparatebau 326 Osterode/Harz) and ground (1 mm screen).

\section{Calculations and statistical analysis}

The apparent digestibility of nutrients and apparent metabolizable energy value were determined by the classical method. $\mathrm{AME}_{\mathrm{N}}$ was corrected to zero nitrogen balance using $34.4 \mathrm{~kJ} / \mathrm{g}$ N retained (Hill and Anderson, 1958). 
Statistical analysis of results was performed using the General Linear Models procedure (GLM) of the $\mathrm{SAS}^{\circledR}$ according to the following general model:

$$
Y i j=\mu+\alpha_{i}+\beta_{j}+(\alpha \beta)_{i j}+\varepsilon_{i j}
$$

where: Y $i j$ - the measured dependent variable; $\mu$ - overall mean; $\alpha_{i}$ - the effect of hominy feed; $\beta_{\mathrm{j}}$ - the effect of enzyme preparation; $(\alpha \beta)_{\mathrm{ij}}$ - the interaction between hominy feed and enzyme preparation; $\varepsilon i j$ - the random error.

Means were compared pair-wise using Duncan's multiple range test. Apparent digestibility of hominy feed and grower diets (experiment two) were analysed separately as two independent experiments.

\section{RESULTS}

The composition of hominy feed was: $\mathrm{g}^{\cdot \mathrm{kg}^{-1}}$ : dry matter 880 ; crude protein 98.6; fat 96.7; crude fibre 50; gross energy $18.9 \mathrm{MJ} \cdot \mathrm{kg}^{-1}$; neutral detergent fibre (NDF), 12.6; acid detergent fibre (ADF) 4.92.

The results of experiment 1 are shown in Table 2. BWG was reduced $(\mathrm{P}<0.05)$ when maize was substituted by hominy feed. Taking into consideration the entire experimental period, the lowest $(\mathrm{P}<0.05)$ BWG were measured in birds fed hominy feed-based diets (B and $\mathrm{B}+\mathrm{E})$. During the entire period (days 1-35 of life), chickens from maize-based diets had better $(\mathrm{P}<0.05) \mathrm{FCR}$ in comparison with the other experimental groups. The worst $(\mathrm{P}<0.05)$ FCR was measured in chickens fed hominy feed B diets.

The use of the enzyme preparation in groups $\mathrm{M}+\mathrm{E}, \mathrm{MB}+\mathrm{E}, \mathrm{B}+\mathrm{E}$ did not influence the FCR and BWG results in relation to groups $\mathrm{M}, \mathrm{MB}$ and $\mathrm{B}$, but a slight tendency to improve the examined parameters was recorded. In the case of BWG and FCR, a statistically significant interaction $(\mathrm{P}<0.05)$ between hominy feed and enzyme supplementation was recorded. Analysis of variance showed that chickens fed the hominy feed diet with the enzyme preparation had better growth performance than those without supplementation $(\mathrm{P}<0.05)$, but in the case of maize diets, enzyme supplementation depressed BWG and FCR. Irrespective of enzyme supplementation and inclusion of hominy feed, no differences were found in the dressing and breast muscles percentage. The only statistically significant differences were in abdominal fat content. Analysis showed that the highest content of abdominal fat was measured in birds fed the enzyme-supplemented hominy feed/maize diet $(\mathrm{P}>0.05)$. The lowest abdominal fat content was recorded in the birds consuming hominy feed $\operatorname{diet}(\mathrm{P}<0.05)$. 


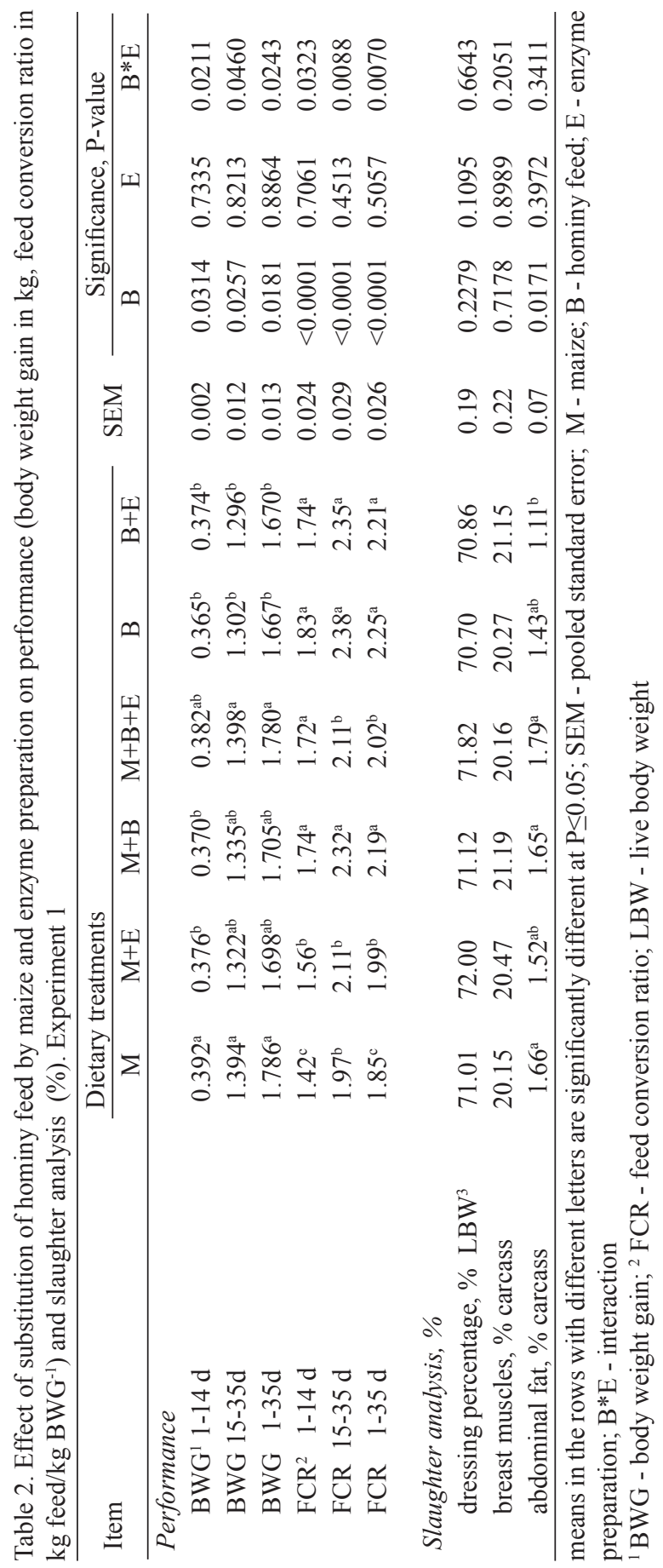


The results obtained in experiment 2 are shown in Tables 3 and 4 . N-free extractives (NFE) digestibility was reduced in an almost linear manner as the concentration of hominy feed in the diet increased $(\mathrm{r}=-0.92)$. The addition

Table 3. Effect of substitution of hominy feed (B) by maize (M) and enzyme preparation on apparent nutrients digestibility and $\mathrm{N}$ retention (in \%) and apparent metabolizable energy $\left(\mathrm{AME}_{\mathrm{N}}\right)$ value (in $\mathrm{MJ} / \mathrm{kg}$ ) of diets. Experiment 2

\begin{tabular}{|c|c|c|c|c|c|c|c|c|c|c|}
\hline \multirow{2}{*}{ Item } & \multicolumn{6}{|c|}{ Dietary treatments } & \multicolumn{4}{|c|}{ Significance, P-value } \\
\hline & $\mathrm{M}$ & $\mathrm{M}+\mathrm{E}$ & $\mathrm{M}+\mathrm{B}$ & $\mathrm{M}+\mathrm{B}+\mathrm{E}$ & B & $B+E$ & & MB & $\mathrm{E}$ & $M B * E$ \\
\hline Organic DM & $76.2^{\mathrm{a}}$ & $76.1^{\mathrm{a}}$ & $72.5^{\mathrm{c}}$ & $74.5^{\mathrm{b}}$ & $70.4^{\mathrm{d}}$ & $71.7^{\mathrm{c}}$ & 0.31 & $<0.0001$ & 0.0035 & 0.0524 \\
\hline Crude fat & $86.7^{\mathrm{c}}$ & $87.9^{\mathrm{c}}$ & $92.7^{\mathrm{ab}}$ & $91.3^{\mathrm{b}}$ & $93.9^{\mathrm{ab}}$ & $94.6^{\mathrm{a}}$ & 0.52 & $<0.0001$ & 0.7894 & 0.3556 \\
\hline $\begin{array}{l}\mathrm{N} \text {-free } \\
\text { extractives }\end{array}$ & $79.3^{\mathrm{a}}$ & $79.4^{\mathrm{a}}$ & $72.5^{\mathrm{c}}$ & $74.6^{\mathrm{b}}$ & $68.4^{\mathrm{d}}$ & $69.8^{\mathrm{e}}$ & 0.54 & $<0.0001$ & 0.0017 & 0.1051 \\
\hline $\mathrm{N}$ retention & $63.5^{\mathrm{bc}}$ & $62.2^{\mathrm{c}}$ & $62.2^{\mathrm{c}}$ & $66.6^{\mathrm{a}}$ & $63.4^{\mathrm{bc}}$ & $65.0^{\mathrm{ab}}$ & 0.34 & 0.0622 & 0.0064 & 0.0007 \\
\hline $\mathrm{AME}_{\mathrm{N}}$ & $13.91^{\mathrm{c}}$ & $14.23^{\mathrm{b}}$ & $14.00^{\mathrm{bc}}$ & $14.48^{\mathrm{a}}$ & $13.32^{\mathrm{e}}$ & $13.57^{\mathrm{d}}$ & 0.06 & $<0.0001$ & $<0.0001$ & 0.3510 \\
\hline
\end{tabular}

means in the rows with different letters are significantly different at $\mathrm{P} \leq 0.05$; DM - dry matter; SEM - pooled standard error; MB - effect of hominy feed; E - effect of enzyme preparation; MB*E - interaction

Table 4. Effect of enzyme preparation on apparent nutrients digestibility and $\mathrm{N}$ retention (\%) and apparent metabolizable energy $\left(\mathrm{AME}_{\mathrm{N}}\right)$ value $(\mathrm{MJ} / \mathrm{kg})$ of maize and hominy feed. Experiment 2

\begin{tabular}{|c|c|c|c|c|c|c|c|c|}
\hline \multirow{2}{*}{ Item } & \multicolumn{4}{|c|}{ Dietary treatments } & \multirow{2}{*}{ SEM } & \multicolumn{3}{|c|}{ Significance, P-value } \\
\hline & PM & $\mathrm{PM}+\mathrm{E}$ & PB & $\mathrm{PB}+\mathrm{E}$ & & MB & $\mathrm{E}$ & $\mathrm{MB} * \mathrm{E}$ \\
\hline Organic DM & $84.1^{\mathrm{a}}$ & $84.4^{\mathrm{a}}$ & $72.5^{\mathrm{b}}$ & $73.5^{\mathrm{b}}$ & 0.89 & $<0.0001$ & 0.3707 & 0.6183 \\
\hline Crude fat & $85.1^{\mathrm{b}}$ & $84.5^{\mathrm{b}}$ & $88.1^{\mathrm{ab}}$ & $89.5^{\mathrm{a}}$ & 0.72 & 0.0048 & 0.7543 & 0.4657 \\
\hline $\mathrm{N}$-free extractives & $90.2^{\mathrm{a}}$ & $89.9^{\mathrm{a}}$ & $73.6^{\mathrm{b}}$ & $75.1^{\mathrm{b}}$ & 1.118 & $<0.0001$ & 0.2934 & 0.1124 \\
\hline $\mathrm{N}$ retention & 45.6 & 45.2 & 48.4 & 45.7 & 0.87 & 0.3578 & 0.3866 & 0.5218 \\
\hline $\mathrm{AME}_{\mathrm{N}}$ & $14.49^{\mathrm{a}}$ & $13.91^{\mathrm{b}}$ & $13.49^{\mathrm{b}}$ & $13.73^{\mathrm{b}}$ & 0.10 & 0.0008 & 0.2740 & 0.0159 \\
\hline
\end{tabular}

means in the rows with different letters are significantly different at $\mathrm{P} \leq 0.05$; DM - dry matter; SEM - pooled standard error; MB - effect of hominy feed; E - effect of enzyme preparation; $M B * E$ - interaction

of the enzyme preparation significantly improved NFE digestibility in the groups where birds were fed hominy feed. Supplementation of the maize/hominy feedbased diets with the feed enzyme improved $(\mathrm{P}<0.05)$ nitrogen retention. Fat apparent digestibility increased as the hominy feed content increased. Hominy feed-based diets had a significantly lower apparent metabolizable energy $\left(\mathrm{AME}_{\mathrm{N}}\right)$ than the maize-based diets (Table 3). Enzyme addition significantly increased the $A M E_{N}$ value in diets by an average of about $0.38 \mathrm{MJ} / \mathrm{kg}$. In diets based exclusively on hominy feed and maize, the digestibility of maize NFE was significantly higher than that of hominy feed (90.2 vs $73.6 \%$; Table 4$)$. There was no difference in nitrogen retention between maize and hominy feed. Fat apparent digestibility was higher $(\mathrm{P}<0.05)$ in hominy feed in comparison with maize. The addition of the 
enzyme preparation had no impact on the utilization of any nutrients. The $\mathrm{AME}_{\mathrm{N}}$ value of maize was significantly higher than in hominy feed and there was no effect of the added enzyme.

\section{DISCUSSION}

The results of the trial demonstrate that nutrient utilization of hominy feed and hominy feed-based diets is lower than of maize and maize-based diets. This is in agreement with the results of Rodrigues et al. (2001). It is likely that the relatively higher NDF content in the diets containing hominy feed was responsible for the poorer $\mathrm{AME}_{\mathrm{N}}$ value and apparent digestibility of $\mathrm{DM}$ and nitrogen retention. The measured performance results are in agreement with the data recorded in experiment 2.

Chesson (2001) showed that maize kernels contain $111 \mathrm{~g} / \mathrm{kg}$ of total non-starch polysaccharides (NSP) with $23 \%$ arabinose and 30\% xylose. The negative effect of total NSP on nutrient digestion and absorption in poultry is well recognized. The soluble fraction of NSP adversely effects digestion and absorption due to increased viscosity of the digesta, but chiefly when the diet is based on wheat or barley. It should be stressed that hominy feed contains mainly insoluble NSP. Water-insoluble NSP can be considered practically indigestible for poultry. As was shown by Kirwan et al. (1974), high level of insoluble fibre in the diet may increase the passage rate of digesta, which can be related to lower nutrient digestion and absorption. This may explain the worst production results when chickens were fed hominy feed-based diets in experiment 1 . The FCR of those chickens was over $21 \%$ worse than of chickens fed maize-based diets.

It can be concluded that the worst utilization of NFE found in groups B, $\mathrm{B}+\mathrm{E}, \mathrm{PB}$ and $\mathrm{PB}+\mathrm{E}$ may be the effect of high non-digestible insoluble NSP concentrations. The ability of chickens to digest plant cell walls is very low (Carré et al., 1990). This is a consequence of the short digesta transit time and also the selective mechanism situated in the caecum-colon region that prevents large cellwall particles from entering the caecum, as well as low cellulolytic activity of caecal bacteria (McNab, 1973; Józefiak et al., 2004).

$A M E_{N}$ recorded in this experiment was lower in the groups fed only hominy feed $(\mathrm{B}, \mathrm{B}+\mathrm{E}, \mathrm{PB}$ and $\mathrm{PB}+\mathrm{E})$. The low values of $\mathrm{AME}_{\mathrm{N}}$ for hominy feed in young chickens were not surprising in view of the corresponding low NFE digestibility. Also other authors (Rodrigues et al., 2001) reported that cereal by-product inclusion may reduce the $\mathrm{AME}_{\mathrm{N}}$ value due to the high level of insoluble NSP. However, it should be emphasized that some authors (Carré, 1990) show that the insoluble NSP exert little effect on nutrient utilization.

It is generally recognized that in chickens, enzyme preparations containing xylanase, $\beta$-glucanase, pectinase and cellulase may improve digestibility of 
nutrients and production results when NSP-rich components are used. Meng and Slominski (2005) reported that NSP-degrading enzyme cocktails may improve production results as well as starch and NSP digestibility within the ileum. It has been proposed that the mode of action of carbohydrase enzymes consists in the degradation of high molecular weight polysaccharides to simple sugars, oligosaccharides, and low molecular weight polysaccharides (Castanon et al., 1997). In the presented experiment, no statistically significant effect of the applied enzyme preparation was found, but a slight tendency to improve digestibility was recorded. It is possible that these improvements were the effect of the enzyme supplementation. Xylanase and pectinase present in the enzyme preparation may degrade cell walls exposing encapsulated nutrients to digestion (Svihus et al., 1997; Meng et al., 2005). This may explain the worst organic dry matter and NFE apparent digestion coefficient when chickens were fed the hominy feed-soyabean meal diet and only hominy feed-based diet without enzyme supplementation in comparison with diets supplemented with the feed enzyme.

It should be emphasized that the presented results are total tract digestibility and the effect of microflora may be significant. Microorganisms compete with the host for the utilization of dietary ingredients in the digestive tract.

The presented results show that hominy feed and enzyme inclusion did not influence slaughter yield. Only in the case of abdominal fat content were some differences recorded. It may be concluded that the lower $\mathrm{AME}_{\mathrm{N}}$ value predisposed to poorer abdominal fat deposition when chickens were fed hominy feed.

\section{CONCLUSIONS}

It can be concluded that use of hominy feed in the diet depresses body weight gain and feed conversion ratio, and that the response to exogenous enzymes was more pronounced in the diets containing higher concentrations of hominy feed.

Future work will focus on the economical impact of hominy feed inclusion and assess the effect of other enzyme combinations on the nutritional value of maize and hominy feed for broilers.

\section{REFERENCES}

AOAC, 1992. Association of Official Analytical Chemists, Official Methods of Analysis. $15^{\text {th }}$ Edition. Washington, DC

Bedford M.R., Morgan A.J., 1996. The use of enzymes in poultry diets. World Poultry Sci. J. 52, 61-68

Boros D., Slominski B.A., Guenter W., Campbell L.D., Jones O., 2004. Wheat by-products in poultry nutrition. Part II. Nutritive value of wheat screenings, bakery by-products and wheat mill run and their improved utilization by enzyme supplementation. Can. J. Anim. Sci. 84, 429-435 
Carré B., 1990. Predicting the energy value of poultry feeds. In: J. Wiseman, D.J.A. Cole (Editors). Feedstuff Evaluation, pp. 283-300

Carré B., Derouet L., Leclercq B., 1990. The digestibility of cell-wall polysaccharides from wheat (bran or whole grain), soybean meal and white lupin meal in cockerels, muscovy ducks, and rats. Poultry Sci. 69, 623-633

Castanon J.I.R., Flores M.P., Pettersson D., 1997. Mode of degradation of non-starch polysaccharides by feed enzyme preparations. Anim. Feed Sci. Tech. 68, 361-365

Chesson A., 2001. Non-starch polysaccharide degrading enzymes in poultry diets: Influence of ingredients on the selection of activities. World Poultry Sci. J. 57, 251-263

Cowieson A.J., 2005. Factors that affect the nutritional value of maize for broilers. Anim. Feed Sci. Tech. 119, 293-305

FAOSTAT Database, 2006. http://www.fao.org/faostat

Hill F.W., Anderson D.L., 1958. Comparison of metabolizable energy and productive energy determinations with growing chicks. J. Nutr. 64, 587-603

Józefiak D., Rutkowski A., Martin S.A., 2004. Carbohydrate fermentation in the avian caeca. A review. Anim. Feed Sci. Tech. 113, 1-15

Kirwan W.O., Smith A.N., McConnell A.A., Mitchell W.D., Eastwood M.A., 1974. Action of different bran preparations on colonic function. Brit. Med. J. 26, 187-189

McNab J.M., 1973. The avian caeca: A review. World Poultry Sci. J. 29, 251-263

Meng X., Slominski B.A., 2005. Nutritive values of corn, soybean meal, canola meal, and peas for broiler chickens as affected by a multicarbohydrase preparation of cell wall degrading enzymes. Poultry Sci. 84, 1242-1251

Meng X., Slominski B., Nyachoti A., Campbell C.M., Guenter L.D., 2005. Degradation of cell wall polysaccharides by combinations of carbohydrase enzymes and their effect on nutrient utilization and broiler chicken performance. Poultry Sci. 84, 37-47

NRC, 1994. Nutrients Requirements of Poultry. $9^{\text {th }}$ Edition. National Academy Press. Washington, $\mathrm{DC}$

Rodrigues P.B., Rostagno H.S., Albino L.F.T., Gomes P.C., Barboza W.A., Santana R.T., 2001. Energy values of millet, corn and corn byproducts, determined with broilers and adult cockerels. Rev. Bras. Zoot. 30, 1767-1778

Slominski B.A., Boros D., Campbell L.D., Guenter W., Jones O., 2004. Wheat by-products in poultry nutrition. Part I. Chemical and nutritive composition of wheat screenings, bakery by-products and wheat mill run. Can. J. Anim Sci. 84, 421-428

Stock R.A., Lewis J.M., Klopfenstein T.J., Milton C.T., 2000. Review of new information on the use of wet and dry milling feed by-products in feedlot diets. J. Anim. Sci. 77, 1-12

Svihus B., Herstad O., Newman C.W., Newman R.K., 1997. Comparison of performance and intestinal characteristics of broiler chickens fed on diets containing whole, rolled or ground barley. Brit. Poultry Sci. 38, 524-529 